\title{
Phosphated fertilization with organic and inorganic amendments in corn crops (Zea mays $\mathrm{L}$.)
}

\author{
Fertilización fosfatada con enmiendas orgánica e inorgánica \\ en maíz (Zea mays L.)
}

\begin{abstract}
Alder-Delosantos Duarte-Monzón ${ }^{1}$; Eugenio González-Caceres²; Jimmy Walter Rasche-Álvarez³; Carlos Leguizamón-Rojas ${ }^{4}$; Diego-Augusto Fatecha-Fois ${ }^{5}$
\end{abstract}

\begin{abstract}
$\frac{\text { ARTICLE DATA }}{1 \text { Research. Msc. Universidad Nacional de Asunción, }}$ San Lorenzo, Paraguay, aduartemonzon@gmail. com

2 Research. Msc. Universidad Nacional de Asunción, San Lorenzo, Paraguay, gonzalezeugenio21@ gmail.com

3 Professor. Ph.D., Universidad Nacional de Asunción, San Lorenzo, Paraguay, jwrasche@yahoo.com.ar

4 Professor. Ph.D. Universidad Nacional de Asunción, San Lorenzo, Paraguay, andresolos@hotmail.com

5 Research. Ph.D. Universidad Nacional de Asunción, San Lorenzo, Paraguay, fatechadiego@hotmail.com
\end{abstract}

Cite: Duarte-Monzón, A.D.; González-Caceres, E.; Rasche-Álvarez, J.; Leguizamón-Rojas, C.; FatechaFois, D.A. (2020). Phosphated fertilization with organic and inorganic amendments in corn crops (Zea mays L.). Revista de Ciencias Agrícolas. 37(2): 27-37.

doi: https://doi.org/10.22267/rcia.203701.132

Received: February 112019.

Accepted: June 022020.

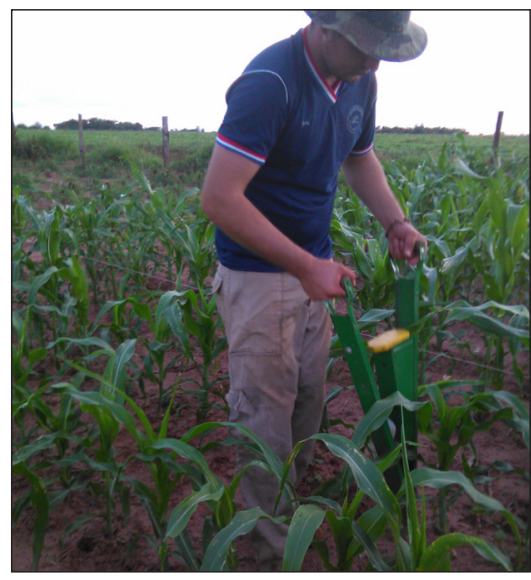

ABSTRACT

The limited availability of phosphorus in most soils in the eastern region of Paraguay restricts the productivity of the chipa corn, where fertilization with phosphates soluble could be one of the alternatives to make up the shortfall nutritional of cultivation. In addition, the combination with amendments makes the use of inorganic fertilizers more efficient in this production system. The work was carried out in the town of Ybyrarobana, Canindeyú, with the aim of to evaluate the effects of phosphorus doses, in combination with organic and inorganic amendments, on corn production. The treatments were distributed in split-plots under a randomized complete block design with 4 blocks. The amendments (bovine manure and ash) and the control occupied the main plots and the doses of $\mathrm{P}_{2} \mathrm{O}_{5}\left(0,40,80,120\right.$ and $\left.160 \mathrm{~kg} \mathrm{ha}^{-1}\right)$ the subplots. Variables such as post-harvest soil fertility, crop growth and yield were determined. The data were subjected to ANOVA and pair-wise comparisons by the Tukey's test with $5 \%$ of probability. Except for the spike length, the evaluated variables showed significant differences between the amendments used. However, there were no statistical differences among doses of P205. The application of bovine manure and soybean expeller ash increased the $\mathrm{pH}$ and exchangeable potassium, and decreased exchangeable aluminum, while the levels of calcium, magnesium and phosphorus were not influenced.

Keywords: Ash; bovine manure; phosphorus; floury corn.

\section{RESUMEN}

La limitada disponibilidad de fósforo en la mayoría de los suelos de la Región Oriental del Paraguay restringe la productividad del maíz chipa, en donde la fertilización con fosfatos solubles podría ser una de las alternativas para compensar ese déficit nutricional del cultivo, además de la combinación con enmiendas hace más eficiente el uso de fertilizantes inorgánicos en este sistema de producción. El trabajo se 
realizó en la localidad de Ybyrarobana, Canindeyú, con el objetivo de evaluar los efectos de dosis de fósforo, en combinación con enmiendas orgánica e inorgánica sobre la producción del maíz. Los tratamientos se distribuyeron en un diseño de bloques completos al azar en parcelas divididas, en 4 bloques. Las enmiendas (estiércol bovino y ceniza) y el testigo ocuparon las parcelas principales y las dosis de $\mathrm{P}_{2} \mathrm{O}_{5}(0,40,80,120$ y $160 \mathrm{~kg} \mathrm{ha}^{-1}$ ) las subparcelas. Se determinaron parámetros químicos del suelo posterior a la cosecha, parámetros de crecimiento y caracteres de rendimiento del cultivo. Los datos fueron sometidos a ANDEVA y comparación de medias mediante el test de Tukey al 5\% de probabilidad. A excepción de la longitud de espiga, las variables evaluadas mostraron diferencias significativas entre las enmiendas utilizadas, sin embargo, no se encontró significancia estadística entre dosis de $\mathrm{P}_{2} \mathrm{O}_{5}$. La aplicación de estiércol bovino y ceniza de expeller de soja aumentaron los valores de $\mathrm{pH}$ del suelo y potasio intercambiable y disminuyeron el aluminio intercambiable, en tanto los tenores de calcio, magnesio y fósforo no fueron influenciados.

Palabras clave: Ceniza; estiércol de bovino; fósforo; maíz harinoso.

\section{INTRODUCTION}

Corn (Zea mays L.) is one of the most important cereals worldwide; it is one of the traditional subsistence crops of peasant families. The corn variety chipá or starch is characterized by grains with endosperm soft, and smooth amylaceous (Acosta, 2009). In Paraguay, the Guaraní indigenous people growth chipá maize and since then it has been rooted in their customs, and inherited from them so far (Rodriguez and Raveri, 2003). In Paraguay, small corn farms (1 -20ha) represent the $88.4 \%$ of the total. It is sown alone or associated with other food crops such as beans (Phaseolus vulgaris L.), pumpkin (Cucurbita maxima ssp.) and cassava (Manihot esculenta Crantz). Corn is used for selfconsumption and cash crop. The average yield of chipa is low with just $1,500 \mathrm{~kg} \mathrm{ha}^{-1}$, growth on soils with low fertility and without fertilization, however, applying technologies, yields can be raised up to 5,000 $\mathrm{kg} \mathrm{ha}^{-1}$ (MAG and DCEA, 2017).

The areas planted with grain crops in soils of the Eastern Region of Paraguay present acidity levels with low phosphorus (P) content available to plants (Bataglia, 2011; Jorge, 2012). In this context, Zambrosi et al. (2012), highlight that the extractions of $\mathrm{P}$ and other nutrients are slowly but progressively impoverishing the soils, which is why it is essential to carry out a good management in order to reduce its loss. Camas et al. (2012) and Almendro et al. (2003), argue that erosion, runoff, washing and extraction by harvest are the main causes of the loss of this element, while other factors such as the fixation and precipitation processes that occur in the soil are not considered losses, but they do reduce its bioavailability.

$\mathrm{P}$ is found in the soil in three fractions, a part in the soil solution, a labile fraction and a nonlabile fraction (Rheinheimer and Anghinoni, 2001). The absorption of $P$ by plants is directly related to its availability, which in turn is influenced by texture, fertilizer dose and by the time of contact with the soil (Vieira et al., 2015). For their part, Oliveira et al. (2014) and Barbieri et al. (2013) highlights $n$ that the higher the clay content in the soil, the higher the adsorption of the $P$ and lower availability. Contact $d$ the $P$ in the solution of the soil with the root is performed almost exclusively by diffusion process in which the element translocate short distances in a stationary aqueous phase, called solution soil, for the concentration gradient. Plants only absorb the $\mathrm{P}$ that is in the soil solution in the form of $\mathrm{H}_{2} \mathrm{PO}_{4}^{-2}$ (diacid phosphate ion) and $\mathrm{HPO}_{4}^{-}$ ${ }^{2}$ (monoacid phosphate ion), (Malavolta, 2004).

With the intensification of agriculture to meet the growing demand for food, the production 
and use of chemical fertilizers have increased, as well as the economic costs that this entails, which in many cases are difficult to achieve for most family producers, for such with organic fertilizer from animal waste, such as bovine manure stool it represents $\mathrm{n}$ a valid alternative to reduce or make use of inorganic fertilizers more efficiently, which are added to the soil to improve their properties, both chemical, physical and biological, promoting plant nutrition, stimulate do the microflora of the soil and increasing yields of crops (Sosa, 2005). Bovine manure in its dry form has relative contents of $\mathrm{N}(2 \%), \mathrm{P}_{2} \mathrm{O}_{5}(1.5 \%), \mathrm{K}_{2} \mathrm{O}$ (2.2\%), Ca (2.9\%) and Mg (0.7\%) (Osorio et al., 2013).

Paraguay produces between 8 to 10 million tons of soybeans per annual harvest, where more than $30 \%$ are destined for industrialization (CAPEC0, 2020), generating significant volumes of waste in the form of expeller and ash, it can be used as soil amendments. The ashes coming from the expeller soybean have an important alkaline character, by the presence of oxides, mainly Ca $(0.25 \%)$ and $\mathrm{Mg}(0.35 \%)$ so it would be possible to use the correction of acidic soil and increasing the $\mathrm{pH}$ value of the soil (Solla et al., 2001), in addition to contributing and increasing its availability of primary elements such as $\mathrm{P}(0.65 \%)$ and $\mathrm{K}(2.5 \%)$, and increasing the activities of decomposing microorganisms of organic matter (Omil, 2007).

Therefore, the objective of the research is to evaluate the effects of the application of bovine manure and soybean expeller ash with phosphorus doses on the production of chipá corn and soil chemical parameters.

\section{MATERIALS AND METHODS}

The study was conducted in the period is september 2015 to february 2016, in the district of Ybyrarobana, Canindeyú Department, Paraguay, located between the geographical

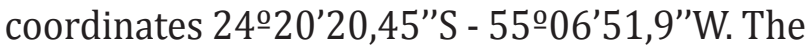
experiment area has a climate subtropical, with average annual temperature of $21^{\circ} \mathrm{C}$ and rainfall reaching $1,600 \mathrm{~mm}$ per year. The predominant soil in the area is classified as Arenic Rhodic Paleudult (Soil Taxonomy, USDA) with sandy texture, low fertility class, good drainage and zero rockiness (Lopez et al., 1995).

Before the installation of the experiment, a physical-chemical analysis of the soil of the 0-20 cm deep layer was carried out (Table 1), verifying acidic $\mathrm{pH}$, harmful exchangeable $\mathrm{Al}^{+3}$, low MO percentage, low available $\mathrm{P}$ content and low exchangeable cations ( $\mathrm{Ca}, \mathrm{Mg}$ and $\mathrm{K}$ ).

Table 1. Physical-chemical characteristics of the soil used in the experiment.

\begin{tabular}{|c|c|c|c|c|c|c|c|c|}
\hline Prof. & pH & MO & $\mathrm{Ca}^{+2}$ & $\mathrm{Mg}^{+2}$ & $\mathbf{K}^{+}$ & $\mathrm{Al}^{+3}$ & $\mathbf{P}$ & Text \\
\hline cm. & $\mathbf{H}_{2} \mathbf{O}$ & $\%$ & -- & 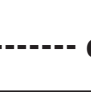 & 1 & & $\begin{array}{c}\mathbf{m g} \\
\mathbf{k g}^{-}\end{array}$ & \\
\hline $0-20$ & 5.1 & 0.9 & 1.13 & 0.29 & 0.11 & 0.63 & 9 & s \\
\hline
\end{tabular}

Extractors: $\mathrm{pH}=\mathrm{H}_{2} \mathrm{O} ; \mathrm{P}$ and $\mathrm{K}^{+}=$Mehlich $-1 ; \mathrm{Ca}^{+2}+\mathrm{Mg}^{+2}$ and $\mathrm{Al}^{+3}=\mathrm{KCl} 1 \mathrm{Mol} \mathrm{L}^{-1} ; \mathrm{s}=$ sandy 
The study was performed on a complete block design to the randomly arranged in plots divided, and $\mathrm{n}$ four blocks, where amendments occupied the main plot and the dose of the phosphorus secondary. The amendments used were bovine manure (30Mg ha-1), soybean expeller ash $\left(0.87 \mathrm{Mg} \mathrm{ha}^{-1}\right)$ and control (without application of amendment).The phosphorus doses applied were $0,40,80,120$ and $160 \mathrm{~kg} \mathrm{ha}^{-1}$ of $\mathrm{P}_{2} \mathrm{O}_{5}$, totaling 60 experimental units. The experimental units had a dimension of $5.0 \mathrm{~m}$ long by $3.5 \mathrm{~m}$ wide $\left(17.5 \mathrm{~m}^{2}\right)$, with five rows of corn chipá, with spacing of 0.70 $\mathrm{m}$ between rows and $0.25 \mathrm{~m}$ between plants, thus obtaining a density of 57.143 plants ha-1.

The source of $\mathrm{P}_{2} \mathrm{O}_{5}$ usedwas triple superphosphate (0-46-0). In all the treatments, $80 \mathrm{~kg} \mathrm{ha}^{-1}$ of $\mathrm{N}$ and $70 \mathrm{~kg} \mathrm{ha}^{-1}$ of $\mathrm{K}_{2} \mathrm{O}$ were applied, using urea (45-0-0) and potassium chloride (0-0-60) as nitrogen and potassium sources, respectively. Soil preparation was in the conventional system, which was performed one plowing tracks and two days. The application of the organic amendments and inorganic fertilizers were carried out manually, fifteen days before the crops were sown.

Sowing was done using seeds without chemical treatment, using the variety Guaraní V 252 (avati moroti ), it was done manually by using a ratchet, depositing 2 seeds per hole, approximately 15 days after emergence, thinning was carried out, leaving one plant per hole.

To control Spodoptera frugiperda was applied insecticide active ingredient Profenofos + Lufen Uron, with doses of $30 \mathrm{~mL}$ in $20 \mathrm{~L}^{-1}$ of water, three times during the cycle, the first 15 days after planting, second at 45 days and the third at 75 days. Weed control was carried out manually, through weekly carpids.

The corn harvest was carried out manually, once the grains reached their physiological maturity. The surface harvested was $2.10 \mathrm{~m}^{2}$, with targeted samples or intentional is considering the central portion of each experimental unit. The variables analyzed were:

Soil chemical parameters. After the crop harvest, five simple samples were extracted to compose a composite sample at a depth of $0-0.10 \mathrm{~m}$ from each experimental unit where the organic amendments with the doses of $\mathrm{P}$ were applied. Once dried sand sieved s to $2 \mathrm{~mm}$ samples the soil were determined: $\mathrm{pH}$ in water; available $\mathrm{K}^{+}$and $\mathrm{P}$ levels, extracted by Mehlich $-1, \mathrm{~K}^{+}$being determined by atomic absorption spectrometry and $\mathrm{P}$ by the colorimetry method; tenors of $\mathrm{Ca}^{+2}$, $\mathrm{Mg}^{+2}$ and $\mathrm{A}$ the ${ }^{+3}$ interchangeable, extracted with $\mathrm{KCl} 1.0 \mathrm{~mol} \mathrm{~L} \mathrm{~L}^{-1}$. A being the $\mathrm{Al}^{+3}$ determined by titration with $\mathrm{NaOH}$ solution $0.015 \mathrm{~mol} \mathrm{~L}^{-1}$ and the $\mathrm{Ca}^{+2}$ and $\mathrm{Mg}^{+2}$ by atomic absorption spectrometry, the OM was determined by the Walkley and Black method.

Stem diameter. Hey were selected 10 plants randomly from cad experimental unit within the area useful, and using a digital caliper was determined the diameter of the stem above the second internode of each plant from the surface of the ground. The measurement was made at the time of physiological maturity of the crop (hard grain), the results were averaged and recorded in millimeters.

Plant height. Of the same 10 plants selected in the used area, the height measurement was done by using measuring tape, measuring from the base of the stem to the tip of the inflorescence male (panicle). The measurement was made when the plant was in physiological maturity, the results of which were averaged and expressed in centimeters.

Number of leaves per plant. They were selected randomly 10 plants of each experimental unit, which were quantified number or sheets, subsequently averaged. 
Spike length. From the selected plants, the spikes were harvested and measured with a ruler graduated in centimeters, from the base to the upper end, discarding the husks, averaged, whose results were expressed in centimeters.

Spike diameter. The same pins chosen for length measurement, were used to determine the diameter, using one digital caliper, and then the data were averaged and recorded in millimeters.

Dry mass of aerial part. Is used five whole plants from the central part of each experimental unit, considering stem, leaves, husks and tassel ears with which were weighed, crushed and mixed. From this mixture, a sample was extracted that was subsequently dried and subjected to an oven at $60^{\circ} \mathrm{C}$ for 72 hours, which was weighed again, whose results were expressed in $\mathrm{kg} \mathrm{ha}^{-1}$.

Performance grain. In the harvested dowels the useful area of each experimental unit $\left(2.10 \mathrm{~m}^{2}\right)$ manually. Subsequently, the shelling was carried out to bag and weigh them with a precision balance, where the results were expressed in $\mathrm{kg} \mathrm{ha}^{-1}$.

Thousand grain weight. In randomly selected from each unid experimental ad 100 grains with eight repetitions, which were weighed using precision scales and averaged by calculating the weight of a thousand grains by simple rule of threes.

The data obtained were subjected to analysis of variance according to the model of divided plots, in the treatments that yielded statistical significance, the comparison of means was carried out with the Tukey test at 95\% probability and regression analysis, using the statistical program InfoStat (Di Rienzo et al., 2008).

\section{RESULTS AND DISCUSSION}

Soil chemical parameters. Soil $\mathrm{pH}$ values both in the control and where the organic amendments were applied showed an acid level $(<5.5)$. However, the application of ash expeller soybean caused increase of the $\mathrm{pH}$, reaching 5.38, differed or statistically obtained from the witness 4.73 . While the $\mathrm{pH}$ of the soil where the application of bovine manure occurred presented a value of 5.23 , without presenting a significant difference compared to the other treatments (Table 2). These results match those obtained by González (2016), in a similar experiment observed change in the $\mathrm{pH}$ of the soil with the application of $0.87 \mathrm{Mg} \mathrm{ha}^{-1}$ ash expeller soybean. The $\mathrm{pH}$ of the soil was not influenced by applying $25 \mathrm{Mg}$ $\mathrm{ha}^{-1}$ of bovine manure, possibly for the little, considering that the ash is an alkaline material, the increase in $\mathrm{pH}$ in the short term was to be expected.

To amendment organic employed caused decrease in the values of a the $\mathrm{Al}^{+3}$ interchangeable, initially with high toxicity $\left(1.1 \mathrm{cmol} \mathrm{kg}^{-1}\right)$ to values low toxicity $(0.47 \mathrm{cmol}$ $\mathrm{kg}^{-1}$ ) but no statistical differences between treatments. The application of bovine manure increased the concentration of exchangeable $\mathrm{K}$ + initially of low level $\left(0.09 \mathrm{cmol}_{\mathrm{c}} \mathrm{kg}^{-1}\right)$ to a maximum value of $0.15 \mathrm{cmol}_{c} \mathrm{~kg}^{-1}$, statistically equal to the treatment with application of ash from soybean expeller, but both superior to the control (Table 2). Likewise, these results were similar to those obtained by González (2016), who, incorporating the same sources and doses of organic amendments, observed an increase in the contribution of $\mathrm{K}^{+}$with values of $0.16 \mathrm{cmol}_{c}$ $\mathrm{kg}^{-1}$ (bovine manure) and $0.14 \mathrm{cmol}_{\mathrm{c}} \mathrm{kg}^{-1}$ (soy expeller ash). According to the analysis of variance and the value of $\mathrm{p}>0.05$, the contents of MO, P, Ca and Mg in the soil, all with initially low levels, were not significantly influenced by the application of the amendments, also without interaction between factors (Table 2). Possibly doses applied amendments seven were low to alter fertility of the soil, mainly short time in the case of the organic amendment. 
Table 2. Soil analysis of the $0-10 \mathrm{~cm}$ litter at the end of the experiment according to sources of amendments. Ybyrarobana,

Canindeyú, Paraguay, 2016.

\begin{tabular}{|c|c|c|c|c|c|c|c|}
\hline $\begin{array}{c}\text { Sources of } \\
\text { amendments }\end{array}$ & $\mathbf{p H}$ & MO & $\mathbf{P}$ & $\mathbf{C a}^{+2}$ & $\mathrm{Mg}^{+2}$ & $\mathbf{K}^{+}$ & $\mathbf{A l}^{+3}$ \\
\hline & & $-\%$ - & $--\mathrm{mg} \mathrm{kg}^{-1}$ - & \multicolumn{4}{|c|}{ - } \\
\hline Ash & $5.38 \mathrm{a}$ & $0.78^{\mathrm{ns}}$ & $8.13^{\mathrm{ns}}$ & $0.63^{\mathrm{ns}}$ & $0.22^{\text {ns }}$ & $0.11 \mathrm{ab}$ & $0.47^{\mathrm{ns}}$ \\
\hline Manure & $5.23 \mathrm{ab}$ & 0.82 & 6.31 & 0.58 & 0.21 & 0.15 to & 0.47 \\
\hline No amendment & $4.73 \mathrm{~b}$ & 0.81 & 7.00 & 0.53 & 0.13 & $0.09 \mathrm{~b}$ & 1.17 \\
\hline
\end{tabular}

$\mathrm{CV}$, coefficient of variation; ns, not significant. Means followed by different letters differ from each other by Tukey's test at $5 \%$ probability of error.

Growth parameters of culture corn. According to the analysis of variance, as variables height of plant, number of leaves per plant, air dry mass and diameter of the stem had significant effect by applying the amendments organic, whose averages were above is to the control, but no differences between both and without interaction between factors. These results are similar to those obtained by Lopez et al. (2015), who, when applying the same treatments in relation to amendment in the same crop, obtained increases of $0.35 \mathrm{~m}$ in plant height and $5850 \mathrm{~kg} \mathrm{ha}^{-1}$ in aerial dry mass. Similarly, Rivas (2018) applying 0 to $15 \mathrm{Mg}$ $\mathrm{ha}^{-1}$ of bovine manure with doses of 0 to $140 \mathrm{~kg}$ ha-1 of $\mathrm{P}_{2} \mathrm{O}_{5}$ observed an increase in plant height, stem diameter and dry mass area of up to $0.66 \mathrm{~m}$, $0.55 \mathrm{~mm}$ and $2.882 \mathrm{~kg} \mathrm{ha}^{-1}$ respectively compared to the control. Sowever, Longoria (2000) found no statistical significance manure bovine incorporate plant height corn diameter of the stem and dry air mass, with mean values of $2 \mathrm{~m} ; 2.28 \mathrm{~cm}$ and $108 \mathrm{~g}$ $\mathrm{pl}^{-1}$ respectively.

The use of organic amendments in this experiment, caused a greater availability of nutrients, satisfying to a great extent the demand from the chipá corn, promoting an increase in its growth parameters. Bovine manure is made up of liquid droppings, as well as solid droppings, the latter constituting the main source of $\mathrm{N}$, an essential element that favors greater vegetative development (Van Raij, 2011).

As for the dose of $\mathrm{P}_{2} \mathrm{O}_{5}$ applied no difference found $\mathrm{s}$ significant $\mathrm{s}$ on the same variables analyzed, nor was interaction observed between both. However, a slight trend of increase is observed depending on the maximum dose of $80 \mathrm{~kg} \mathrm{ha}^{-1}$ of $\mathrm{P}_{2} \mathrm{O}_{5}$ (Table 3). These results coincide with Alvarado (2002), who did not find differences in the height of the corn plant due to the application of increasing doses of $\mathrm{P}$. 
Table 3. Plant height, number of leaves per plant, aerial dry mass and diameter of the corn stem as a function of $\mathrm{P}_{2} \mathrm{O}_{5}$ doses and sources of amendments. Ybyrarobana, Canindeyú, Paraguay, 2016.

\begin{tabular}{|c|c|c|c|c|c|}
\hline $\begin{array}{l}\text { Amendment Factor } \\
\text { Sources }\left(\mathrm{Mg} \mathrm{ha}^{-1}\right)\end{array}$ & Dose & $\begin{array}{c}\text { Plant } \\
\text { height }\end{array}$ & $\begin{array}{l}\text { Leaves } \\
\text { plant }^{-1}\end{array}$ & $\begin{array}{l}\text { Aerial dry } \\
\text { mass }\end{array}$ & $\begin{array}{c}\text { Stem } \\
\text { diameter }\end{array}$ \\
\hline & & $----m---$ & -number- & $\mathrm{kg} \mathrm{ha}^{-1}$ & ----mm---- \\
\hline Bovine manure & 30 & 2,47 a & 14,67 a & $12.757 \mathrm{a}$ & 23,06 a \\
\hline Ash & 0,87 & $2,42 a b$ & $14,32 \mathrm{ab}$ & $12.122 \mathrm{ab}$ & $22,75 \mathrm{a}$ \\
\hline No amendment & 0 & $2,35 \mathrm{~b}$ & $14,09 \mathrm{~b}$ & $10.842 \mathrm{~b}$ & $21,37 \mathrm{~b}$ \\
\hline General average & & 2,41 & 14,36 & 11.907 & 22,39 \\
\hline \multicolumn{6}{|c|}{ Phosphorus Factor Dose $\left(\mathrm{kg} \mathrm{ha}^{-1}\right)$} \\
\hline \multirow{5}{*}{$\mathrm{P}_{2} \mathrm{O}_{5}$} & 0 & $2.38^{\mathrm{ns}}$ & $14.18^{\mathrm{ns}}$ & $11,30^{\mathrm{ns}}$ & $21.79^{\text {ns }}$ \\
\hline & 40 & 2.39 & 14.35 & 12,184 & 22.00 \\
\hline & 80 & 2.48 & 14.59 & 12,322 & 22.94 \\
\hline & 120 & 2.41 & 14.29 & 11,577 & 22.81 \\
\hline & 160 & 2.40 & 14.38 & 12,151 & 22.42 \\
\hline CV\% & & 4.20 & 4.18 & 14.21 & 6.46 \\
\hline General average & & 2.41 & 14.36 & 11,907 & 22.39 \\
\hline
\end{tabular}

$\mathrm{CV}$, coefficient of variation; ns, not significant. Means followed by different letters differ from each other by Tukey's test at $5 \%$ probability of error.

Characters of the cultivation of the corn. The shank diameter and thousand seed weight showed significant increases by application of cattle manure and soybean expeller ash when compared to the control, and both shank lengths, not was influenced. Rivas (2018) applying 0 to $15 \mathrm{Mg} \mathrm{ha}^{-1}$ of manure with increasing doses up to $140 \mathrm{~kg} \mathrm{ha}^{-1}$ of $\mathrm{P}_{2} \mathrm{O}_{5}$, as in the evaluated growth parameters, observed a significant effect with maximum values of $3.59 \mathrm{~cm}$ in diameter of spikes and 241g in the weight of a thousand seeds. Meanwhile Longoria (2000) using the same treatments with organic amendment, it did not find significant differences in the length and diameter shank of corn yield overall mean of 28 and $4.63 \mathrm{~cm}$ respectively.
Furthermore, no statistical significances were detected between treatments at doses of $\mathrm{P}$ and with no interaction between factors, for the parameters of spike length, shank diameter and thousand kernel weight (Table 4) that obtained average values of $17.04 \mathrm{~cm} ; 37.61 \mu \mathrm{m}$ and $223 \mathrm{~g}$, respectively. In the same way, Salvador (2016) and Romero (2017) to the fertilizer apply phosphating not observed influence to about the length and the diameter of pins corn coinciding with the results obtained in this investigation, showing that short term is difficult to obtain response to the application of deteriorated soils. The length and diameter shank in corn is a self-genotypic characteristic of each cultivar, influenced sometimes by external factors as the humidity of the soil and plant density. 
Table 4. Spike length, spike diameter and weight of a thousand corn grains based on $\mathrm{P}_{2} \mathrm{O}_{5}$ doses and sources of amendments.

Ybyrarobana, Canindeyú, Paraguay, 2016.

\begin{tabular}{|c|c|c|c|c|}
\hline \multicolumn{5}{|c|}{ Amendment Factor } \\
\hline Sources $\left(\mathrm{Mg} \mathrm{ha}^{-1}\right)$ & Dose & $\begin{array}{l}\text { Spike } \\
\text { length }\end{array}$ & $\begin{array}{c}\text { Shank } \\
\text { diameter }\end{array}$ & $\begin{array}{l}\text { Thousand } \\
\text { grain weight }\end{array}$ \\
\hline & & ---- cm ---- & ---- mm ---- & ---- g ---- \\
\hline Bovine manure & 30 & $17.13^{\mathrm{ns}}$ & $37.92 \mathrm{a}$ & $230 \mathrm{a}$ \\
\hline Ash & 0.87 & 17.24 & $37.80 \mathrm{ab}$ & $224 \mathrm{ab}$ \\
\hline No amendment & 0 & 16.76 & $37.10 \mathrm{~b}$ & $215 \mathrm{~b}$ \\
\hline General average & & 17.04 & 37.61 & 223 \\
\hline \multicolumn{5}{|c|}{ Phosphorus Factor } \\
\hline Dose (kg ha-1) & Dose & $\begin{array}{l}\text { Spike } \\
\text { length }\end{array}$ & $\begin{array}{c}\text { Shank } \\
\text { diameter }\end{array}$ & $\begin{array}{l}\text { Thousand } \\
\text { grain weight }\end{array}$ \\
\hline \multirow{5}{*}{$\mathrm{P}_{2} \mathrm{O}_{5}$} & 0 & $16.82^{\mathrm{ns}}$ & $37.22^{\mathrm{ns}}$ & $219^{\mathrm{ns}}$ \\
\hline & 40 & 16.60 & 37.81 & 220 \\
\hline & 80 & 17.33 & 37.82 & 222 \\
\hline & 120 & 17.39 & 37.75 & 231 \\
\hline & 160 & 17.07 & 37.44 & 222 \\
\hline CV\% & & 4.63 & 2.73 & 6.04 \\
\hline General average & & 17.04 & 37.61 & 223 \\
\hline
\end{tabular}

$\mathrm{CV}$, coefficient of variation; ns, not significant. Means followed by different letters differ from each other by Tukey's test at $5 \%$ probability of error.

The yield of corn grains was significantly influenced by the application of bovine manure and soybean expeller ash, obtaining values of $4.692 \mathrm{~kg} \mathrm{ha}^{-1}$ and $4.395 \mathrm{~kg} \mathrm{ha}^{-1}$ exceeding the treatment without application of amendment in $761 \mathrm{~kg} \mathrm{ha}^{-1}$ and $464 \mathrm{~kg} \mathrm{ha}^{-1}$ respectively (Table 5).

Applying MO through manure bovine is widely used in most crop farming, in order to improve and maintain the conditions of the soil and increasing agricultural productivity, particularly their high concentration of $\mathrm{N}$ on dry matter (1.6\%) that applied doses of $30 \mathrm{Mg} \mathrm{ha}{ }^{-1}$, contributes approximately $130 \mathrm{~kg} \mathrm{ha}^{-1}$ of $\mathrm{N}$ available to the crop, assuming $45 \%$ mineralization of $\mathrm{N}$ and 60 $\%$ efficiency of use of mineralized $\mathrm{N}$ (FigueroaViramontes et al., 2010). This can be corroborated in other experiments such as González (2016), who using the same variety of corn, with the same treatments of this experiment, observed that grain yield increased up to $15 \%$ in relation to the control.
Table 5. Yield of corn grains according to sources of amendments, Ybyrarobana, Canindeyú, Paraguay, 2016.

\begin{tabular}{|c|c|c|}
\hline \multicolumn{3}{|c|}{ Amendment Factor } \\
\hline Sources $\left(\mathrm{Mg} \mathrm{ha}^{-1}\right)$ & Dose & Grain yield \\
\hline & & --- $\mathrm{kg} \mathrm{ha}^{-1}$---- \\
\hline Bovine manure & 30 & $4.692 \mathrm{a}$ \\
\hline Ash & 0.87 & $4.395 \mathrm{ab}$ \\
\hline No amendment & 0 & $3.931 \mathrm{~b}$ \\
\hline General average & 0.61 & 4,339 \\
\hline \multicolumn{3}{|c|}{ Phosphorus Factor } \\
\hline \multirow[t]{2}{*}{ Dose (kg ha-1) } & Dose & Grain yield \\
\hline & & ---- kg ha-1 ---- \\
\hline \multirow{5}{*}{$\mathrm{P}_{2} \mathrm{O}_{5}$} & 0 & $4099 \mathrm{~ns}$ \\
\hline & 40 & 4370 \\
\hline & 80 & 4407 \\
\hline & 120 & 4754 \\
\hline & 160 & 4067 \\
\hline CV\% & 6.4 & 6.04 \\
\hline General average & & 4352 \\
\hline
\end{tabular}

CV: coefficient of variation; Means followed by different letters differ from each other by Tukey's test at 5\% probability of error. ns: not significant. 
Likewise, Rivas (2018) applying 7 and $15 \mathrm{Mg}$ ha $^{-1}$ of bovine manure on deteriorated soil, found considerable increases in grain yield, initially from $779 \mathrm{~kg} \mathrm{ha}^{-1}$ in the control to $2,952 \mathrm{~kg} \mathrm{ha} \mathrm{ha}^{-1}$ and $4,061 \mathrm{~kg}^{-1} \mathrm{ha}^{-1}$ respectively. No significant difference was found between the doses of $\mathrm{P}_{2} \mathrm{O}_{5}$ or interaction between factors. The results do not match Salvador (2016), who found increases in grain yield of the corn a fertilized or with $\mathrm{P}$ and compared to treatment without $\mathrm{P}$, with a difference of $1503 \mathrm{~kg} \mathrm{ha}^{-1}$. On the other hand, Alvarado (2002), obtained increases of $857 \mathrm{~kg} \mathrm{ha}^{-1}$ in the yield of corn grains, applying $70 \mathrm{~kg} \mathrm{ha}^{-1}$ of $\mathrm{P}_{2} \mathrm{O}_{5}$, compared to the control.

This s results in the parameters of performance of maize, it can be a result, that only the approximately $20 \%$ of phosphorus $\left(\mathrm{P}_{2} \mathrm{O}_{5}\right)$ applied is used by cultivation in the first year, because the phosphorus released can be adsorbed by soil colloids or form insoluble iron and aluminum compounds (Silva, 2007).

It is estimated that another factor that could influence the non-response of corn to the doses of $\mathrm{P}_{2} \mathrm{O}_{5}$ was the non-application of agricultural lime, since the soil where the experiment was implanted initially presented strongly acidic $\mathrm{pH}$ (Table 1), decreasing the availability of $\mathrm{P}$, therefore its absorption by the corn crop. The not applying agricultural lime obeys to determine the effect of amendments organic acid on the levels of the ground, determined by the values of $\mathrm{pH}$ and $\mathrm{Al}^{+3}$ the interchangeable.

Also can highlight, is that the ground is in a state of extreme deterioration in their fertility levels and the dose of organic amendments with P applied via chemical fertilization, is rum in sufficient a period of one year for recovery, mainly when relate to the activity micro biological, increase in the content of organic matter and supply of nutrients, not meeting even beneficiaries significates, that for more that provide high amounts in many situations, the former initial terms limitations of the soil, not only in its chemical properties but also in physics, by initially presenting high levels of compaction, significantly reduce the response of crops to applied fertilizers, whether chemical or organic.

\section{CONCLUSION}

Under the conditions of this study, the application of phosphorus doses in combination with bovine manure and soybean expeller ash increased corn production.

\section{ACKNOWLEDGEMENT}

To CONACYT for financing part of the work within the framework of project 14-INV-130 called "Sustainable management of soil fertility for food production".

To the Faculty of Agrarian Sciences of the National University of Asunción for the support through the use of infrastructure and equipment necessary for field and laboratory work.

To Mr. Alejandro Duarte Sanabria for providing the infrastructure and land for the experiment.

Conflict of interest: The authors declare that there is no conflict of interest.

\section{BIBLIOGRAPHIC REFERENCES}

Acosta, R. (2009). El cultivo del maíz, su origen y clasificación. El maíz en cuba. Cultivos Tropicales. 30(2):113-120.

Almendro, M.B.; Navarro, J.; Jordán, M.M.; Gómez, I (2003). Movilidad y biodisponibilidad del fósforo en un Antrosol del Sureste Español (Alicante) enmendado con lodo de depuradora. Rev. Edafología. 10 (1):7-14. 
Alvarado, LC. (2002). Respuesta del maíz (Zea mays L.) a la fertilización con nitrógeno, fósforo, potasio y zinc en suelos del norte de Tamaulipas. Recovered from http://eprints.uanl. $\mathrm{mx} / 932 / 1 / 1080124385 . P D F$

Barbieri, D.M.; Júnior, J.M.; Pereira, G.T.; La Scala, N.; Siqueira, D.; Panosso, A.R. (2013). Comportamento dos óxidos de ferro da fração argila e do fósforo adsorvido, em diferentes sistemas de colheita de cana-de-açúcar. Rev. Bras. Ciên. Solo. 37(6):1557-1568. doi: http://dx.doi. org/10.1590/S0100-06832013000600012

Bataglia, V. (2011). Clasificación de los niveles de acidez activa $(\mathrm{pH})$ y necesidad de cal agrícola de los suelos de la Región Oriental del Paraguay. Recovered from http://www.agr.una.py/fca/ index.php/tesis/catalog/book/119

Capeco - Cámara Paraguaya de Exportadores y Comercializadores de Cereales y Oleaginosas. (2020). Área de Siembra, Producción y Rendimiento. Recovered from http://capeco.org. py/area-de-siembra-produccion-y-rendimiento/

Camas, R.; Turrent, A.; Cortes, J.; Livera, M.; González, A.; Villar, B.; López, J.; Espinoza, N.; Cadena, P. (2012). Erosión del suelo, escurrimiento y pérdida de nitrógeno y fósforo en laderas bajo diferentes sistemas de manejo en Chiapas, México. Rev. Mex. Cienc. Agríc. 3(2): 231-243.

Di Rienzo, J.A.; Casanoves, F.; Balzarini, M.G.; Gonzalez, L.; Tablada, M.; Robledo, C.W. (2008). InfoStat, version 2008, InfoStat Group. Argentina: FCA, National University of Córdoba.

Figueroa-Viramontes, U.; Cueto-Wong, J.; Delgado, J.; Núñez-Hernández, G.; Reta-Sánchez, D.; QuirogaGarza, H.; Contreras, R.; Márquez-Rojas, J. (2010). Estiércol de bovino lechero sobre el rendimiento y recuperación aparente de nitrógeno en maíz forrajero. Terra Latinoamérica. 28(4): 361- 369.

González, E. (2016). Aplicación de dosis de nitrógeno con enmiendas orgánica e inorgánica en maíz chipá (Zea mays var. amiláceo L.). Recovered from http://www.agr.una.py/fca/index.php/libros/ catalog/book/303

Jorgge, V. (2012). Clasificación de niveles de Fosforo de los suelos de la Región Oriental del Paraguay. http://www.agr.una.py/fca/index.php/tesis/ catalog/book/56
Longoria, CS. (2000). Fertilización orgánica con estiércol bovino en diferentes fechas y dosis de aplicación en maíz blanco hualahuises. Recovered from http://eprints.uanl. $\mathrm{mx} / 6353 / 1 / 1080095037 . P D F$

Lopez, M.J.; Figueroa, U.; Fortis, M.; Nunez, G.; Ochoa, E.; Sánchez, J.I. (2015). Evaluación de dosis equivalentes de fertilizante y estiércol en la producción de maíz forrajero (Zea mays). Rev. Inter. Boot. Exper. 84 (1) 8-13.

Lopez, O.; González, E.; De Llamas, P.; Molinas, A.; Franco, E.; García, S.; Rios, E. (1995). Estudio de reconocimiento de suelos, capacidad de uso de la tierra y propuesta de ordenamiento territorial preliminar de la región Oriental del Paraguay. Asunción, PY: MAG/Banco Mundial/Gobierno del Japón/Servicio Geodésico Interamericano. Escala 1:500.000. Color. Recovered from http:// www.geologiadelparaguay.com/Estudio-deReconocimiento-de-Suelos Regi\%C3\%B3nOriental-Paraguay.pdf

MAG - Ministerio de Agricultura y Ganadería; DCEA Dirección de Censos y Estadísticas Agropecuarias. (2017). Sintesis Estadísticas. Producción Agropecuaria. Año agrícola 2016/2017. ecovered from http://www.mag.gov.py/Censo/ SINTESIS\%20ESTADISTICA_final_08.01.2018a.pdf

Malavolta, E. (2004). Fósforo na Agricultura Brasileira: o fósforo na planta e interações com outros elementos. 3rd ed. Piracicaba (BR). Brazil: Associação Brasileira para Pesquisa da Potassa e do Fósforo. 98 p.

Oliveira, C.M.; Gatiboni, L.C,; Miquelluti, D.J.; Smyth, T.J.; Almeida, J.A. (2014). Capacidade máxima de adsorção de fósforo e constante de energia de ligação em Latossolo bruno em razão de diferentes ajustes do modelo de langmuir. Rev. Bras. Science. Alone. 38 (6): 1805-1815. doi: http://dx.doi. org/10.1590/S0100-06832014000600015

Omil, B. (2007). Gestión de cenizas como fertilizante y enmendante de plantaciones jóvenes de Pinus radiata. Recovered from https://docplayer. es / 16202612 -Gestion-de-cenizas-comofertilizante-y-enmendante-de-plantacionesjovenes-de-pinus-radiata.html

Osorio, M.E.; Mesías, J.M.; Araya, R. (2013). Stabilized cattle manure and boron damage in lettuce (Lactuca sativa L.) cv. from the river, 
in the Lluta valley, Chile. IDESY. 31(1): 1525. doi: http://dx.doi.org/10.4067/S071834292013000100003

Rheinheimer, D.; Anghinoni, I. (2001). Distribution of inorganic phosphorus in single-use handling systems. Pesq. Agrop. Bras. 36(1):151160. doi: https://doi.org/10.1590/s0100204x2001000100019

Rivas, A. (2018). Fertilización phosphated cattle manure and n corn chipa in the district Caaguazú. Recovered from https://sopacis.org.py/wpcontent/uploads/2019/03/I-CONGRESO-ALTOPARANA.pdf

Rodríguez, C.; Rabery, S. (2003). Rendimiento del maíz amiláceo variedad avati moroti sembrado en dos épocas y tres distancias entre hileras. Investigated. Agrar. 35 (2): 30-36.

Romero, V.D. (2017). Fuentes de fósforo y promotores de crecimiento (PGPR) en maíz chipa (Zea mays var. amylacea sturtev). Recovered from https:// sopacis.org.py/wp-content/uploads/2019/03/ I-CONGRESO-ALTO-PARANA.pdf

Salvador, L.S. (2016). Fuentes de fósforo con promotores de crecimiento (PGPR) en cultivo de maíz chipa (Zea mays L. var. amylacea Sturtev.). Recovered from https://app.luminpdf.com/view er/5f8d816a8a34b80011a7a3f1

Silva, J.A. (2007). Aplicação inicial de P205 no solo, avaliação em três cultivos sucessivos no feijão-caupi. Recovered from http://livros01. livrosgratis.com.br/cp027203.pdf

Solla, F.; Rodríguez, R.; Merino, A. (2001). Evaluación del aporte de cenizas de madera como fertilizante de un suelo ácido mediante un ensayo en laboratorio. Rev. Inves. Agrar. Produc and Protec. Veg. 16 (3): 379-393.

Sosa, 0. (2005). Los estiércoles y su uso como enmiendas orgánicas. Agrom. 16 (80): 30-34.

Van Raij, B. (2011). Fertilidade de solo e manejo de nutrientes. Piracicaba: International Plant Nutrition Institute. 420p.

Kennneth, E. K.; Kendall J. (2005). Análisis y diseño de sistemas. $8^{\circ}$ ed. México: Pearson Educación. 726p.
Vieira, R.C.; Fontoura, S.M.; Bayer, C.; De Moraes, R.P.; Carniel, E. (2015). Adubação Fosfatada para Alta Produtividade de Soja, Milho e Cereais de Inverno Cultivados em Rotação em Latossolos em Plantio Direto no Centro-Sul do Paraná. Rev. Bras. Hundred. Alone. 39 (3): 794-808. doi: http:// dx.doi.org/10.1590/01000683rbcs20140463

Zambrosi, F.C.; Mattos, D.; Furlani, P.R.; Quaggio, J.A.; Boaretto, R.M. (2012). Eficiência de absorção e utilização de fósforo em porta-enxertos cítricos. Rev. Bras. Hundred. Alone. 36 (2): 485496. doi: http://dx.doi.org/10.1590/S010006832012000200018 